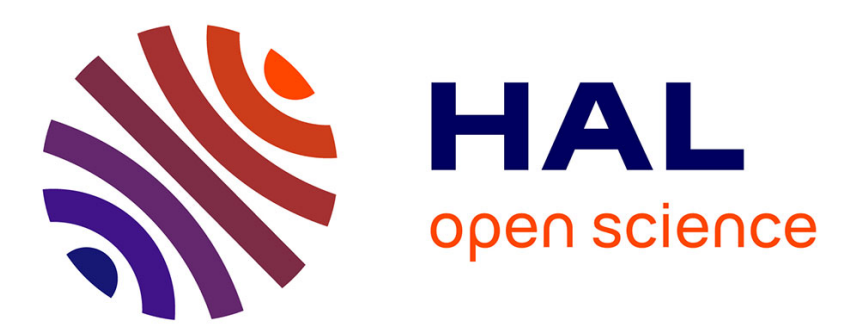

\title{
Contribution of gene-modified mice and rats to our understanding of the cardiovascular pharmacology of serotonin.
}

Laurent Monassier, Marc André Laplante, Tarak Ayadi, Stéphane Doly, Luc

Maroteaux

\section{To cite this version:}

Laurent Monassier, Marc André Laplante, Tarak Ayadi, Stéphane Doly, Luc Maroteaux. Contribution of gene-modified mice and rats to our understanding of the cardiovascular pharmacology of serotonin.. Pharmacology and Therapeutics, 2010, 128 (3), pp.559-67. 10.1016/j.pharmthera.2010.08.004. inserm-00549197v2

\section{HAL Id: inserm-00549197 https://www.hal.inserm.fr/inserm-00549197v2}

Submitted on 29 Jan 2019

HAL is a multi-disciplinary open access archive for the deposit and dissemination of scientific research documents, whether they are published or not. The documents may come from teaching and research institutions in France or abroad, or from public or private research centers.
L'archive ouverte pluridisciplinaire HAL, est destinée au dépôt et à la diffusion de documents scientifiques de niveau recherche, publiés ou non, émanant des établissements d'enseignement et de recherche français ou étrangers, des laboratoires publics ou privés. 
Contribution of gene-modified mice and rats to our understanding the cardiovascular pharmacology of serotonin.

Laurent Monassier ${ }^{1,2^{*}}$, Marc André Laplante ${ }^{1}$, Tarak Ayadi ${ }^{1}$, Stéphane Doly ${ }^{3}$ and Luc Maroteaux ${ }^{3}$.

1 Laboratoire de Neurobiologie et Pharmacologie Cardiovasculaire, "Physiopathologie et Médecine Translationnelle" EA 4438, Faculté de Médecine, 11 rue Humann, 67085 Strasbourg France.

${ }^{2}$ Mouse Clinical Institute, 1 rue Laurent Fries, BP 10142, 67404 Illkirch Cedex France.

${ }^{3}$ INSERM U839, Institut du Fer à Moulin, 17 rue du Fer à Moulin, 75005 Paris France.

Keywords: serotonin, development, pulmonary, hypertension, hemostasis, cardiac hypertrophy, cytokines.

* Author for correspondence:

Laurent Monassier, Laboratoire de Neurobiologie et Pharmacologie Cardiovasculaire, "Physiopathologie et Médecine Translationnelle" EA 4438, Faculté de Médecine, 11 rue Humann, 67085 Strasbourg France.

Tel: +33368 853392 Fax: +33368 853388

e-mail : Laurent.Monassier@medecine.u-strasbg.fr 


\begin{abstract}
This review focuses on new insights provided by transgenic animals in the cardiovascular pharmacology of serotonin. During development, mice mutant for tryptophan hydroxylase-1 lacking peripheral serotonin or for $5-\mathrm{HT}_{2 \mathrm{~B}}$ receptors display cardiac defects and dilated cardiomyopathy. The 5- $\mathrm{HT}_{4}$ receptor is also important for the maturation of cardiac conduction system. In fact, transgenic approaches revealed that adult cardiac status is strongly influenced by maternal serotonin. Long ago, serotonin was identified as a vasoconstrictor in adult physiology. Analysis of transgenic animals knocked-out for the serotonin transporter suggested a role of this protein in blood pressure control and revealed an effect of 5- $\mathrm{HT}_{2 \mathrm{~B}}$ receptor antagonists in hypertension. Concerning lung vasculature, mice lacking 5- $\mathrm{HT}_{2 \mathrm{~B}}$ receptor gene exposed to chronic hypoxia are resistant to pulmonary hypertension, while 5$\mathrm{HT}_{1 \mathrm{~B}}$ receptor and serotonin transporter mutant animals show partial resistance. In platelets, serotonin transporter mutant mice revealed that this transporter regulates not only the mechanisms by which serotonin is packaged and secreted but also their aggregation. Concerning adult cardiac remodeling, fibroblasts from mice lacking 5- $\mathrm{HT}_{2 \mathrm{~B}}$ receptor gene were unable to secrete cytokines and were protected from cardiac hypertrophy induced by isoproterenol and angiotensin II stimulations. Crossing these animals with mice overexpressing the receptor in cardiomyocytes revealed the contribution of cardiac fibroblasts and $5-\mathrm{HT}_{2 \mathrm{~B}}$ receptors in cardiac hypertrophy. In mice lacking monoamine oxidase-A gene, the role of serotonin degradation in cardiac hypertrophy was firmly confirmed. In conclusion, transgenic animals contributed strongly to the re-evaluationof the influence of serotonin on cardiovascular regulation, though several unknowns remain to be investigated.
\end{abstract}




\section{Introduction}

The first description of serotonin (5-Hydroxytryptamine, 5-HT) effects was in the cardiovascular field when, in 1896, Weiss showed that the response elicited by intravenous injection of serum in dogs was not reproduced by plasma administration (Weiss, 1896). The identification of the active compound, took half a century with two major steps. The first was achieved when Vially and Erspamer purified from enterochromaffin cells a substance inducing the contraction of smooth muscle cells (Vially and Erspamer, 1933). This substance called enteramine was, in a second step, identified as 5-hydroxytryptamine/5-HT as a blood vessel contracting molecule (Rapport et al., 1948a, b). Serotonin has been mainly studied for its role in the central nervous system. Only recently, its contribution to the peripheral cardiovascular system was emphasized especially in the regulation of platelet aggregation and regulation of cerebral blood flow.

One important feature of the serotonergic system is a great plasticity and capability to be mobilized in pathological context. In fact, most of the 5-HT effects are not detected in normal animals or humans, but appear only when a stressor is applied. In such ways, hypoxia revealed a role for the 5-HT transporter (SERT) (Wanstall JC et al., 2003), 5- $\mathrm{HT}_{1 \mathrm{~B}}$ receptors $\left(5-\mathrm{HT}_{1 \mathrm{~B}} \mathrm{R}^{-/}\right.$) (Keegan et al., 2001), and 5- $\mathrm{HT}_{2 \mathrm{~B}}$ receptors $\left(5-\mathrm{HT}_{2 \mathrm{~B}} \mathrm{R}^{-/-}\right.$) (Launay et al., 2002) in pulmonary hypertension. Likewise, myocardial injury identified $5-\mathrm{HT}_{4} \mathrm{R}$ re-expression and contribution to the cardiac inotropism of the failing heart (Qvigstad E et al., 2005). Moreover, transgenic mice studies gave new insights in 5-HT contribution to development and cardiac morphogenesis.

Serotonin is mainly ( $>95 \%$ ) localized in the periphery, in circulating platelets from which it is released by activation. Serotonin is loaded into platelets via SERT after synthesis in the intestinal wall (Figure 1) (for a review on the serotonergic system see Jonnakuty and Gragnoli C, 2008). 5-HT is synthesized by enterochromaffin cells and released in the portal circulation. The synthesis of this simple mediator, derived from the essential aminoacid Ltryptophan, is rate limited by tryptophan-hydroxylase 1 (Tph-1) activity, the Tph-2 isoform being the central nervous system enzyme. Serotonin demonstrates several, and sometimes opposite, cardiovascular effects. This surprisingly wide spectrum of effects is in fact due to numerous target receptors. To date, 16 receptors, subclassified in 4 groups, have been identified: $5-\mathrm{HT}_{1 / 5}, 5-\mathrm{HT}_{2}, 5-\mathrm{HT}_{3}$, and $5-\mathrm{HT}_{4 / 6 / 7}$. The classification is based upon the main intracellular coupling of these receptors (Figure 2). The 5- $\mathrm{HT}_{3 \mathrm{~A}-\mathrm{E}}$ are ion channels when the others are G-proteins coupled receptors: Gi for 5- $\mathrm{HT}_{1 / 5}$, Gs for 5- $\mathrm{HT}_{4 / 6 / 7}$ and $\mathrm{Gq}$ for $5-\mathrm{HT}_{2}$. In 
some subclasses, different members were identified. As an example, the 5- $\mathrm{HT}_{2} \mathrm{Rs}$ group consists in 3 members: 5 -HT $2 \mathrm{~A}_{2 \mathrm{~B}}$ and ${ }_{2 \mathrm{C}}$. In the cardiovascular system, the serotonergic receptors distribution pattern is species-dependent (shown in Figure 3 for mice). In this review, we will focus on the insights of transgenic animals to cardiovascular pharmacology of the ubiquitous transmitter 5-HT.

\section{The serotonergic system and cardiac morphogenesis}

In mice, 5- $\mathrm{HT}_{2 \mathrm{~B}} \mathrm{Rs}$ are highly expressed during early phases of embryogenesis starting at E8 in many places such as neuroepithelium, notocord, somits, neural crest cells, and myocardium (Choi et al., 1997; Lauder et al., 2000). In cultured mouse embryos, pharmacological blockade of $5-\mathrm{HT}_{2 \mathrm{~B}} \mathrm{Rs}$ by ritanserin induced malformations of the cephalic region, the heart and the neural tube indicating a possible contribution of this receptor in development (Choi et al., 1997). The firm demonstration of 5-HT embryonic functions was initially provided by mice knocked-out for 5- $\mathrm{HT}_{2 \mathrm{~B}} \mathrm{R}\left(5-\mathrm{HT}_{2 \mathrm{~B}} \mathrm{R}^{-/}\right)$by homologous recombination. This mutation induced a partial lethality around 10 days embryogenesis that was apparently due to cardiac defects (Nebigil et al., 2001).

The alterations were similar to those observed in neuregulin and ErbB-2 knockout animals indicating that the Gq-coupled 5- $\mathrm{HT}_{2 \mathrm{~B}} \mathrm{R}$ could use ErbB-2 tyrosine kinase pathway in cardiac differentiation and growth. Mice that were able to reach the adulthood showed a leftventricular dilatation and fibrillar disorganization, males being more affected than females. Such a gender difference has been observed in other transgenic mice presenting a cardiomyopathy (Berul et al., 1998). Surprisingly, despite a reduced number of cardiomyocytes, size reduction of individual cells and cytoarchitectural abnormalities, the in vivo cardiac contractility was preserved. It is to note that $5-\mathrm{HT}_{2 \mathrm{~B}} \mathrm{R}^{-/-}$mice never showed any trouble of the cardiac conduction or arrhythmias leading to the conclusion that this receptor is mostly involved in embryonic differentiation and growth of the cardiomyocytes. This appears different from 5-HT $\mathrm{HT}_{4}$ Rs: Newborns from pregnant female mice immunized against $5-\mathrm{HT}_{4} \mathrm{R}$, demonstrate major troubles of the intracardiac conduction with frequent atrioventricular block (Kamel et al., 2007). Surprisingly, such a phenotype has not yet been described in 5-HT $\mathrm{R}^{-/-}$ animals.

Although the role of $5-\mathrm{HT}_{2 \mathrm{~B}} \mathrm{R}^{-/-}$in development is now established, the origin and requirement of 5-HT itself is still a matter of debate. Some insights are provided by SERT gene targeting. This transporter regulates extracellular 5-HT concentrations, its inhibition 
being responsible for local increase in extracellular 5-HT concentrations. By using Cre/lox conditional transgenic reporter mice, SERT has been shown to be expressed in the embryonic heart, starting at E10.5, in the outflow tract, part of right ventricle and to a very limited extent in the left ventricle (Pavone et al., 2007). Its expression co-localizes with Islet 1 in leftventricular ejection chamber and right ventricle (E11.5) and with connexin-43 in atrioventricular valves (Pavone et al., 2008). Taken together, these data indicate that a regulation of extracellular 5-HT concentration could affect development without providing information on the origin of 5-HT.

Recently, the group of Francine Côté, Guilan Vodjdani, and Jacques Mallet characterized a mouse strain disrupted for the gene encoding the peripheral Tph-1 (Cote et al., 2007). These animals demonstrate a preserved cardiac ultrastructure but a dilated cardiomyopathy with reduced contractility leading to heart failure. In the heart of these animals, 5-HT concentration was reduced 10 times compared to controls but the authors failed to show any 5-HT synthesis in myocardial tissue and left open the question on the origin of cardiac 5-HT during embryogenesis. Interestingly, newborns from genetic phenylketonuric patients show mental retardation and cardiac abnormalities (Roux et al., 1995). The high phenylalanine concentration induced a competitive inhibition of tryptophan hydroxylases and so, a massive reduction of maternal 5-HT plasma concentration. A diet with reduced phenylalanine is required to prevent fetal abnormalities. This observation drives the concept that maternal 5-HT could contribute to embryonic development.

In a subsequent study, Francine Côté et al. intercrossed Tph- $1^{+/+},{ }^{+/-}$and ${ }^{-/-}$females with Tph- $1^{+/+},{ }^{+/}$and ${ }^{-/-}$males and investigated offspring for embryonic abnormalities (Fligny et al., 2008). The result was remarkable, $80 \%$ of heterozygous embryos from Tph- ${ }^{-/-}$mothers were small with or without abnormalities as compared to $3.7 \%$ in heterozygous from Tph- $1^{+/-}$ mothers. Moreover, surviving adult $\mathrm{Tph}-1^{-/-}$mice exhibited a progressive dilated cardiomyopathy that was more severe when born from homozygous mutant mothers than heterozygous. These results clearly show that adult cardiac status is strongly influenced by maternal serotonergic status.

Overall, these data showed that early fetal 5-HT concentration depends on maternal transplacental delivery and SERT fetal activity. They both contribute to the regulation of 5HTR activation including $5-\mathrm{HT}_{2 \mathrm{~B}} \mathrm{Rs}$ that are required for normal cardiac morphogenesis and growth. 


\section{The serotonergic system in cardiovascular regulation}

3.1 Regulation of the vascular tone of systemic arteries (central and peripheral aspects)

More than a century ago, 5-HT was described as a blood pressure regulator, but, despite many years of intensive research, the contribution of 5-HT to blood pressure control is still an area of controversy. Plasma 5-HT is increased in human hypertension and deoxycorticosterone (DOCA)-salt hypertensive rats, and a nearly full serotonergic system is found in peripheral arteries. These vessels can synthesize, capture, store and metabolize this mediator and arterial walls express $5-\mathrm{HT}_{1 \mathrm{~B}}, 2 \mathrm{~A}$ and ${ }_{2 \mathrm{~B}}$ serotonergic receptors. In the late $1970 \mathrm{~s}$, the $5-\mathrm{HT}_{2} \mathrm{R}$ antagonist ketanserin was clinically used as an antihypertensive compound but the reduction of blood pressure was attributed to its affinity for $\alpha_{1}$-adrenergic receptors, ruling out a possible role for 5-HT in systemic pressure control. This postulate was confirmed by the absence of effect of ritanserin, a non-selective $5-\mathrm{HT}_{2} \mathrm{R}$ antagonist that lacks $\alpha$-adrenergic receptor affinity. At the opposite, 5-HT infusion or administration of the selective $5-\mathrm{HT}_{2 \mathrm{~B}} \mathrm{R}$ antagonist LY272015 were shown to reduce blood pressure in hypertensive rats, driving the hypothesis that the serotonergic system could act differently when blood pressure is normal or elevated (Watts, 2009). This group suggested that functional changes of 5- $\mathrm{HT}_{2 \mathrm{~B}}$ but not 5$\mathrm{HT}_{1 \mathrm{~B}} \mathrm{Rs}$ play a role in the development of DOCA-salt hypertension (Banes and Watts, 2003).

Data obtained in transgenic animals were limited with most investigators using SERT knockouts as models to elucidate the contribution of 5-HT by reducing its extracellular clearance. The consequences of SERT suppression can be analyzed in two different species i.e. rats and mice. $\mathrm{SERT}^{-/-}$rats were obtained through $\mathrm{N}$-ethyl-N-nitrosurea mutagenesis (Homberg et al., 2006; Homberg et al., 2007). SERT ${ }^{-/-}$mice and rats show very low blood 5HT concentrations and do not demonstrate any blood pressure phenotype supporting an absence of role for 5-HT to blood pressure homeostasis and/or compensatory mechanisms in rodents (Ni et al., 2008). Nevertheless, Homberg et al. (2006) also analyzed heterozygous rats and observed a small increase in systolic blood pressure. This result is interesting because, at the opposite to homozygous knockouts, the platelets 5-HT content is normal in heterozygous animals. Therefore, 5-HT at physiological blood concentration could increase blood pressure if SERT is partially inhibited. This physiological role of SERT was emphasized by the group of S. Watts that showed a leftward shift of the dose response curve to 5-HT in wild-type rats aortic rings treated with the SERT inhibitor, fluvoxamine (Linder et al., 2008). This phenomenon was not observed in aorta from $\mathrm{SERT}^{-/-}$rats arguing in favor of a compensatory mechanism in these animals. 
If all these data indicate that SERT function has little impact on the resting blood pressure regulation, the system may be relevant in the context of a high blood pressure. This hypothesis was tested in rats heterozygous and homozygous for SERT mutation and chronically submitted to the NO synthase inhibitor N-nitro-L-arginine. The authors did not identify blood pressure phenotype among the three genotypes. Nevertheless, heterozygous rat's blood pressure was still higher than controls, the difference observed in basal conditions being maintained or slightly increased vs. controls in hypertensive conditions (Homberg et al., 2006). Similarly, when $\mathrm{SERT}^{-/-}$mice and rats were submitted to a DOCA-salt regimen, their blood pressure increase was important but quite similar to controls ( $\mathrm{Ni}$ et al., 2008). In this model, partly depending on the serotonergic system, the lack of difference in $\mathrm{SERT}^{-/-}$rats could partly be explained by the low blood 5-HT and does not rule out any contribution of a $5-\mathrm{HT}_{2 \mathrm{~B}} \mathrm{R}$ overexpression in hypertension as suggested by the LY272015 effect. The 5- $\mathrm{HT}_{2 \mathrm{~B}} \mathrm{R}^{-}$ 1- mouse was characterized for resting blood pressure and did not demonstrated any difference compared to controls. Similarly, the selective 5- $\mathrm{HT}_{2 \mathrm{~B}} \mathrm{R}$ antagonists SB215505 and SB206553 neither affected basal blood pressure nor response to a 14 days angiotensin II infusion (Monassier et al., 2008). In depth investigations should now be done in hypertensive knockout models for the arterial 5- $\mathrm{HT}_{2 \mathrm{~A}},{ }_{2 \mathrm{~B}}$ and ${ }_{1 \mathrm{~B}} \mathrm{Rs}$. Transgenic animals will also offer the opportunity to dissect 5-HT pharmacology in other vascular beds such as coronary and cerebral circulations.

\subsection{Regulation by 5-hydroxytryptamine of hypoxia-induced pulmonary vascular remodeling}

In recent years, several studies have demonstrated that 5-HTRs control hypoxic responses in the pulmonary vascular system (Farber and Loscalzo, 2004). Unlike hypoxic responses in central nervous system, which involve many different 5-HTR subtypes, hypoxia-induced vasoconstriction in pulmonary vasculature appears to involve only $5-\mathrm{HT}_{1 \mathrm{~B}}$ and $5-\mathrm{HT}_{2 \mathrm{~A}, 2}{ }_{\mathrm{B}} \mathrm{Rs}$. The exact pathways through which hypoxia causes vasoconstriction and pulmonary vascular remodeling (PVR) are just beginning to be identified. What is clear, however, is that hypoxia alters molecular (e.g., protein expression) and cellular (e.g., proliferation) processes via mechanisms that involve 5-HT, its receptors, and its transporter to elicit the physiological, pulmonary responses to hypoxia (vasoconstriction and PVR). In wild-type mice, hypoxia increases right ventricular pressure and pulmonary vascular remodeling. These effects of hypoxia are attenuated in the tryptophan hydroxylase $1^{-/-}$mice (Morecroft et al., 2007). In the chronic-hypoxic-mouse model of pulmonary hypertension, plasma 5-HT levels are significantly increased after chronic exposure to hypoxia in wildtype mice. 


\subsubsection{Hypoxic conditions modify 5-hydroxytryptamine levels}

The function of 5-HTRs in hypoxic responses in the pulmonary vasculature must be dependent on the presence of suitable 5-HT levels activating these receptors. In healthy subjects, unconjugated plasma 5-HT levels are low $(<10 \mathrm{nM})$; however, in PH patients, plasma 5-HT is consistently elevated (Herve et al., 1990; Herve et al., 1995; Kereveur et al., 2000). A deficiency in platelet 5-HT storage, as in Fawn hooded rats, contributes to the development of severe PH under both normoxic (Kentera et al., 1988) and hypoxic (high altitude) (Sato et al., 1992) conditions. These observations suggest an etiological role for 5HT in the development of $\mathrm{PH}$ and raise two important questions: 1) what is the source of 5HT in pulmonary vasculature, and 2) how does reduced $\mathrm{O}_{2}$ lead to an increase in plasma 5-HT levels?

In the periphery, 5-HT is synthesized and secreted from neuroendocrine enterochromaffin cells in the gut. Serotonin is mainly eliminated by uptake in lung either by endothelial cells, where it is then degraded by monoamine oxidase-A (MAO-A) (Vane, 1957) or by platelets. Platelets take up 5-HT through SERT and store- but only slowly degradethe monoamine. Former studies have shown that long-term hypoxia causes a decrease in platelet counts and short-term hypoxia increases platelet counts (McDonald et al., 1978). Later, it has been established that chronic hypoxia, a stimulator of erythropoiesis, causes thrombocytopenia in laboratory animals. The thrombocytopenia is most likely the result of a reduction in the production of platelets caused by a decrease in the number of megakaryocytes in bone marrow. The thrombocytopenia seems to be caused by competition of precursor cells to erythrocytic and megakaryocytic lineages (McDonald et al., 1992). Moreover, hypoxia facilitates platelets aggregation (Li et al., 1997). Alteration of platelet number and/or function under hypoxic conditions could thus concertedly reduce 5-HT uptake and would explain hypoxia-induced increases in circulating plasma 5-HT. In this regard, platelet activation was found in the pulmonary vessels of patients with PH secondary to chronic obstructive pulmonary disease (Rostagno et al., 1991), and platelet survival time is reduced in patients with hypoxemia and PH (Steele et al., 1977). Anti-platelet agents, such as dipyridamole, reduce hypoxemic $\mathrm{PH}$ and the thickness of pulmonary arteries in response to chronic hypoxia (Keith et al., 1987). Based on these results, it has been postulated that circulating plasma 5HT may originate from platelets (Fanburg and Lee, 2000).

Different chemosensory organs such as the carotid bodies (CB) and pulmonary neuroepithelial bodies (NEB) respond to hypoxia in a 5-HT-dependent fashion. CB type I 
cells contain 5-HT and express $5-\mathrm{HT}_{1 \mathrm{~A}}, 5-\mathrm{HT}_{3}$, and $5-\mathrm{HT}_{5 \mathrm{~A}} \mathrm{Rs}$ that may affect $\mathrm{CB}$ function when arterial $\mathrm{pO}_{2}$ is reduced (Kirby and McQueen, 1984). NEBs release 5-HT in response to acute hypoxia by a mechanism involving the 5- $\mathrm{HT}_{3} \mathrm{R}$ (Fu et al., 2002). In this way, cellular and molecular hypoxia-regulated mechanisms, which have an effect on circulating plasma 5HT levels, probably involve platelets and pulmonary NEB, as well as reductions in the lungs' ability to uptake and remove 5-HT. The 5- $\mathrm{HT}_{2 \mathrm{~A}} \mathrm{Rs}$ have been detected in platelets (Cook et al., 1994), where they enhance platelets aggregation ( $\mathrm{Li}$ et al., 1997). The activation of presynaptic 5-HT ${ }_{1 \mathrm{~B}} \mathrm{R}$ decreases 5-HT release (Davidson and Stamford, 1996), and in neonatal rabbit pulmonary NEB, 5- $\mathrm{HT}_{3} \mathrm{Rs}$ are involved in a positive feedback loop resulting in hypoxia-induced 5-HT release (Fu et al., 2002). In mice with either genetically or pharmacologically inactive $5-\mathrm{HT}_{2 \mathrm{~B}} \mathrm{Rs}$, plasma 5-HT levels were not modified by chronic hypoxia (Launay et al., 2002). Interestingly, an acute agonist stimulation of 5- $\mathrm{HT}_{2 \mathrm{~B}} \mathrm{R}$ triggers a transient increase in plasma 5-HT that is SERT dependent and blocked by $5-\mathrm{HT}_{2 \mathrm{~B}} \mathrm{R}$ selective antagonist or genetic ablation, supporting the notion that a $5-\mathrm{HT}_{2 \mathrm{~B}} \mathrm{R}$-dependent regulation of 5-HT uptake is implicated in the control of plasma 5-HT levels (Callebert et al., 2006). Together these observations suggest that 5-HTRs control plasma levels of their ligand in response to hypoxia.

\subsubsection{Putative role of serotonin transporter in hypoxic pulmonary vascular} remodeling

In recent years, many studies have explored possible roles of SERT in hypoxia-induced PVR. Hypoxia causes changes in SERT expression: acute and chronic hypoxia increase SERT mRNA levels in rat pulmonary arteries (Eddahibi et al., 1999). Upon acute hypoxia, specific 5-HT transport is increased in porcine pulmonary artery endothelial cells without a concomitant increase in $K_{\mathrm{m}}$. Acute hypoxia results in an elevation of the maximal uptake rate $\left(V_{\max }\right)$, implying de novo protein synthesis, and modification of plasma membrane phospholipids and fluidity (Bhat and Block, 1990). Conversely, chronic hypoxia reduces 5HT uptake by pulmonary arteries (MacLean et al., 2004; Launay et al., 2002).

In rat pulmonary artery smooth muscle cells (SMC), stimulation by 5-HT leads to an increase in DNA synthesis, and acute hypoxia potentiates this mitogenic effect. The increase in DNA synthesis can be prevented by high concentrations of SERT inhibitors (Lee et al., 1991). Nonetheless, in sodium-free conditions (i.e., without 5-HT uptake), SERT inhibitors still attenuated 5-HT-induced mitogenesis (Pitt et al., 1994). Importantly, some SERT inhibitors (including citalopram and fluoxetine) have $\mu \mathrm{M}$ affinities for $5-\mathrm{HT}_{2} \mathrm{R}$ (Sanchez and 
Hyttel, 1999). In chronic hypoxic mice, increased PVR is partially reduced by the SERT inhibitors citalopram and fluoxetine (Marcos et al., 2003). Recent results indicate that there is synergy between the inhibitory effects of 5-HT ${ }_{1 B} \mathrm{R}$ antagonists and SERT inhibitors on 5-HTinduced pulmonary vasoconstriction (Morecroft et al., 2005) and that nordexfenfluramine (NorDF)-induced vasoconstriction is not dependent on SERT-mediated release of endogenous 5-HT but rather via direct activation of 5-HTRs (Ni et al., 2005). These observations suggest that 5-HT uptake by SERT cannot fully account for the action of 5-HT, and support a role for 5-HTRs. The proposition that the long SERT promoter polymorphism promotes PVR through increased SERT expression does not fully explain why patients who develop PH after dexfenfluramine (DF) treatment have the same proportion of this polymorphism as do $\mathrm{PH}$ patients in general (Rabinovitch, 2001). Moreover, the report that PVR after chronic hypoxia is reduced — but not completely abolished — in mice deficient for SERT gene (Eddahibi et al., 2000) demonstrates that SERT does not solely mediate hypoxia-induced PVR.

\subsubsection{Regulation of hypoxia-induced pulmonary vascular remodeling by 5-} hydroxytryptamine serotonin receptors

Different mechanical factors have been shown to induce PVR. Chronic hypoxia can stimulate PVR directly and/or by a persistent vasoconstriction process as already suggested (Jeffery and Wanstall, 2001). Despite sustained hypoxia, vasoconstriction persists but subsides somewhat as PVR progresses (Reeves et al., 1986). Neurohumoral factors such as 5-HT/5-HTRs may be implicated. The 5- $\mathrm{HT}_{1 \mathrm{~B}} \mathrm{R}$-mediated acute contractile response to 5-HT is increased in pulmonary arteries isolated from chronic hypoxic wild-type mice. However, $5-\mathrm{HT}_{1 \mathrm{~B}} \mathrm{R}$ knockout mice still respond to hypoxia but develop less severe PH and PVR than do wildtype mice (Keegan et al., 2001). Discordantly, Marcos et al. report that chronic hypoxia (10\% $\mathrm{O}_{2}$ for 2 weeks)-induced pulmonary hypertension and increased vessel muscularization were not reduced by the 5-HT $1 \mathrm{~B} / 1 \mathrm{D}$ R antagonist GR127935 (Marcos et al., 2003). Thus, the role of $5-\mathrm{HT}_{1 \mathrm{~B}} \mathrm{R}$ in hypoxia-induced PH and PVR remains unclear and may be species- or strainsensitive.

In ovine common carotid arteries, despite altering the contractile response, acute hypoxia had no effect on $5-\mathrm{HT}_{2 \mathrm{~A}} \mathrm{R}$ coupling to $\mathrm{IP}_{3}$ second-messenger production (Angeles et al., 2001). Similarly, acute hypoxia reduced 5-HTRs density and agonist affinity in adult bovine common carotid arteries (Angeles et al., 2000). However, the role of 5-HT ${ }_{2 A} \mathrm{R}$ in hypoxia-induced PH and PVR is not clear, since the receptor's expression is not modified in the lung vasculature of mice exposed to $10 \% \mathrm{O}_{2}$ for 5 weeks or in human $\mathrm{PH}$ (Launay et al., 
2002). Furthermore, in mice, the effects of chronic hypoxia on pulmonary artery pressure and vessel muscularization are insensitive to the $5-\mathrm{HT}_{2 \mathrm{~A}} \mathrm{R}$ antagonist ketanserin (Marcos et al., 2003).

Mice with pharmacologically or genetically inactive 5- $\mathrm{HT}_{2 \mathrm{~B}} \mathrm{R}$ do not develop $\mathrm{PH}$ and PVR following chronic hypoxia, even though the acute hypoxic response (vasoconstriction) is intact (Launay et al., 2002). Therefore, the $5-\mathrm{HT}_{2 \mathrm{~B}} \mathrm{R}$ is a key factor in the molecular signaling pathways that couple chronic hypoxia to PH and PVR, a pathway independent of acute hypoxia-induced vasoconstriction, for a review see (Esteve et al., 2007). The 5-HT ${ }_{2 B} R$ also functionally interacts with the 5- $\mathrm{HT}_{1 \mathrm{~B}} \mathrm{R}$ and the SERT, whose roles in $\mathrm{PH}$ and PVR are rather well established. For instance, $5-\mathrm{HT}_{1 \mathrm{~B}} \mathrm{R}$ and SERT activities are modulated by $5-\mathrm{HT}_{2 \mathrm{~B}} \mathrm{Rs}$ (Fanburg and Lee, 2000; Tournois et al., 1998). Similarly, MacLean proposed a functional interaction between $\mathrm{G}_{\mathrm{i}}$-coupled $\left(5-\mathrm{HT}_{1 \mathrm{~B}} \mathrm{R}\right)$ and the SERT, which would facilitate the development of PH (Morecroft et al., 2005). In addition, SERT, 5-HT ${ }_{1 B} R$, and 5- $\mathrm{HT}_{2 \mathrm{~B}} \mathrm{R}$ are colocalized in pulmonary arteries, and $5-\mathrm{HT}_{2 \mathrm{~B}} \mathrm{R}$ has been reported to regulate SERT activity in the 1C11 serotonergic cell line (Launay et al., 1998). The emerging question, then, is how 5-HTRs control hypoxia-induced PVR.

\section{Platelets and hemostasis}

We have previously emphasized that peripheral 5-HT is mainly found in circulating platelets. Once 5-HT enters the circulation, it is captured inside platelets by SERT and then sequestered in dense granules by the vesicular monoamine transporter (VMAT-2). This phenomenon is critical for a normal platelet aggregation because rats lacking SERT demonstrate a reduced hemostasis as attested by a bleeding time prolongation (Matondo et al., 2009) The current dogma is that 5-HT released during platelet activation amplifies, in an autocrine manner, the effect of other prothrombotic agents through activation of 5-HT $\mathrm{H}_{2 \mathrm{~A}} \mathrm{Rs}$. Nevertheless, some non5-HT $\mathrm{H}_{2 \mathrm{~A}}$-mediated effects of 5-HT were identified.

Recently, work with transgenic mice has provided new informations about the crucial role of platelet's SERT to fill 5-HT stores. The homozygous disruption of integrin $\beta 3$ in Itgb3/- mice did not affect the SERT expression level but markedly reduced 5-HT platelet uptake. At the opposite, when platelets were seeded on the $\alpha \operatorname{IIb} \beta 3$ ligand, fibrinogen, the 5-HT uptake was increased together with an enhancement of SERT membrane expression and/or catalytic function through pathways linked to p38 MAPK. These observations made in transgenic animals lead to the discovery of a direct molecular interaction between the SERT 
C-terminus and the $\alpha \mathrm{IIb} \beta 3$ integrin. Moreover, the expression of an overactive integrin $\beta 3$ increased fibrinogen binding, platelet reactivity to ADP and 5-HT uptake. This SERT overactivity was due to an increased plasma membrane location of the transporter via an enhanced p38 MAPK signaling. Taken together, these data support a role of integrins on SERT activity by direct molecular interaction and phosphorylation.

Transgenic mice also shed new light on another crucial role of platelet SERT, direct regulation of aggregation. Platelets isolated from $\mathrm{SERT}^{-/-}$mice show a $80 \%$ reduction of ADP induced aggregation and a 50\% reduction to thrombin indicating agonist dependent roles for the SERT in the extent of platelet aggregation (Carneiro et al., 2008). This role is located in a final common pathway leading to aggregation. After being captured, platelet 5-HT is stored in dense granules also containing ADP, ATP and calcium. Rab27b is a GTP binding protein that was originally purified in platelets. Tomalchova et al. (2007) demonstrated that Rab27b is a key regulator of dense granule secretion. Its absence leads to a major reduction of 5-HT, ATP and $\alpha$-granule proteins secretion. 5-HT secretion is tightly regulated: Mice lacking serglycin, an hematopoietic cell secretory granule proteoglycan, demonstrate a reduced secretion of dense granule 5-HT and ATP contributing to a lower ability to aggregate and to bind fibrinogen (Woulfe et al., 2008).

Activated platelets bind numerous adhesive and procoagulant proteins by receptormediated processes. Although little evidence suggests that these processes are heterogeneous in platelets, platelets co-stimulated with collagen and thrombin express functional $\alpha$-granule factor $\mathrm{V}$ only on a subpopulation of cells, referred to as 'COAT-platelets', which then bind additional $\alpha$-granule proteins, including fibrinogen, von Willebrand factor, thrombospondin, fibronectin and $\alpha 2$-antiplasmin. These proteins are all transglutaminase substrates, and transglutaminase inhibitors prevent the production of COAT-platelets. COAT-platelets use 5HT conjugation to augment the retention of procoagulant proteins on their cell surface (Dale et al., 2002). Mice selectively deficient in peripheral Tph-1 exhibited impaired hemostasis, resulting in a reduced risk of thrombosis and thromboembolism, although the ultrastructure of platelets was not affected. While aggregation of 5-HT-deficient platelets in vitro is apparently normal, their in vivo adhesion is reduced due to a blunted secretion of adhesive $\alpha$-granular proteins. It has been shown that 5-HT is transamidated to small GTPases by transglutaminases during activation and aggregation of platelets, rendering these GTPases constitutively active. Thus, a receptor-independent signaling mechanism, now termed "serotonylation," leads to $\alpha$ granule exocytosis from platelets (Walther et al., 2003). 
The small $\mathrm{G}$ protein RhoA plays a major role in several vascular processes and cardiovascular disorders. Serotonin is associated with RhoA both in vitro and in vivo, via transamidation by transglutaminase. Transamidation leads to RhoA activation and enhanced proteasomal degradation, which in turn is responsible for Akt activation and contraction inhibition (Guilluy et al., 2007). RhoA and Rho kinase activities are increased in pulmonary hypertension, which has recently been associated with enhanced RhoA serotonylation (Guilluy et al., 2009). High extracellular 5-HT induces also transamidation of the small GTPase, Rab4. Modification with 5-HT stabilizes Rab4 in its active, GTP-bound form, Rab4GTP (Ahmed et al., 2008). The covalent coupling of 5-HT by transglutaminases has been extended during insulin exocytosis to two key players in insulin secretion, the small GTPases Rab3a and Rab27a. Serotonylation renders them constitutively active in a receptorindependent signaling mechanism. Concordantly, an inhibition of such activating serotonylation in $\beta$-cells reduces insulin secretion. Serotonylated Rab3a is inactivated by enhanced proteasomal degradation, as other serotonylated GTPases. Serotonin can thus regulate insulin secretion by serotonylation of GTPases within pancreatic $\beta$-cells (Paulmann et al., 2009). Serotonin can covalently modify other proteins integral to contractility and the cytoskeleton, in particular, smooth muscle $\alpha$-actin that can be serotonylated (Watts et al., 2009). Finally, Rac1 activity is transiently increased due to transglutaminase-catalyzed transamidation of 5-HT to Rac1 via stimulation of 5-HT ${ }_{2 A}$ Rs. Activation of Rac1 via transglutaminase is therefore a novel effector and second messenger of the $5-\mathrm{HT}_{2 \mathrm{~A}} \mathrm{R}$ signalling cascade (Dai et al., 2008).

\section{Cardiac remodeling}

The idea that 5-HT could interfere with cardiac remodeling has been proposed 20 years ago when clinical trials showed the cardiac antihypertrophic effect of the non-selective $5-\mathrm{HT}_{2} \mathrm{R}$ antagonist, ketanserin, in hypertension and heart failure (Brune et al., 1990; Vyssoulis et al., 1990). Unfortunately, clinical applications of this drug were blunted by a non-5-HTRs mediated QT interval prolongation and the risk of sudden cardiac death. This effect, entirely due to a blockade of inward rectifying HERG channels (Tu et al., 2008), deeply affected this field of research and reduced the interest of the serotonergic system in the heart.

In the late $90 \mathrm{~s}$, the characterization of a mouse mutant line lacking the $5-\mathrm{HT}_{2 \mathrm{~B}}$ subtype of 5- $\mathrm{HT}_{2} \mathrm{Rs}$ demonstrated a constitutive reduction of the left-ventricular mass with fewer and smaller cardiomyocytes than wild-type mice (Nebigil et al., 2001). This global hypoplasia led 
to an enlarged ventricle and a small reduction of the cardiac contractility. A similar phenotype was obtained in mice lacking Tph-1, the peripheral isoform of tryptophan hydroxylase (Côté et al., 2003), indicating that peripheral 5-HT is necessary for cardiac development, possibly through a 5- $\mathrm{HT}_{2 \mathrm{~B}} \mathrm{R}$ stimulation. At the opposite, overexpression of this Gq-coupled receptor in cardiomyocytes induced a mild hypertrophic cardiomyopathy (Nebigil et al., 2003). Taken together, all these data showed the importance of this receptor in myocardial tropic responses.

The fact that many serotonergic agonists are known to produce fibrosis focused attention on functions of 5-HTRs in extracellular cell matrix regulation. Cardiac fibroblasts express both $5-\mathrm{HT}_{2 \mathrm{~A}}$ and $5-\mathrm{HT}_{2 \mathrm{~B}} \mathrm{Rs}$ and activation of the later produces the release of IL-6, IL-1 $\beta$, TGF- $\beta$ and TNF $\alpha$. Moreover, cardiac hypertrophy induced by a 5 days-long infusion of the $\beta$-adrenergic agonist, isoproterenol, was prevented by a selective $5-\mathrm{HT}_{2 \mathrm{~B}} \mathrm{R}$ antagonist and in 5- $\mathrm{HT}_{2 \mathrm{~B}} \mathrm{R}^{-/-}$mice (Jaffre et al., 2004). This prevention was observed in parallel with a reduction of the plasma concentration of these cytokines and without any effect on heart rate or blood pressure. In this model, a reduction of cardiac contractility was observed, attesting of a progressive evolution of ventricular function towards failure that was prevented by $5-\mathrm{HT}_{2 \mathrm{~B}} \mathrm{R}$ blockade. The hypothesis that cardiac hypertrophy could be linked to myocardial cytokines production and oxidative stress was tested. When wild-type mice treated with a $5-\mathrm{HT}_{2 \mathrm{~B}} \mathrm{R}$ antagonist or $5-\mathrm{HT}_{2 \mathrm{~B}} \mathrm{R}^{-/-}$mice were infused with isoproterenol or angiotensin II, the pharmacologically induced cardiac hypertrophy was prevented in parallel with a major reduction of left ventricular superoxide anion concentration (Monassier et al., 2008). Interestingly, in the angiotensin II model, superoxide anion generation in the aorta of these hypertensive animals, a tissue expressing very low amounts of $5-\mathrm{HT}_{2 \mathrm{~B}} \mathrm{Rs}$, was not prevented by $5-\mathrm{HT}_{2 \mathrm{~B}} \mathrm{R}$ blockade. Oxidative stress was mainly mediated by an overexpression of the $\mathrm{NAD}(\mathrm{P}) \mathrm{H}$ oxidase; $5-\mathrm{HT}_{2 \mathrm{~B}} \mathrm{R}$ blockade did not affect this increased expression but reduced the enzyme activity.

To analyze the respective contribution of $5-\mathrm{HT}_{2 \mathrm{~B}} \mathrm{Rs}$ expressed by fibroblasts and cardiomyocytes in antihypertrophic action of $5-\mathrm{HT}_{2 \mathrm{~B}} \mathrm{R}$ antagonists, double transgenics were generated by crossing $5-\mathrm{HT}_{2 \mathrm{~B}} \mathrm{R}^{-/-}$mice and mice overexpressing the $5-\mathrm{HT}_{2 \mathrm{~B}} \mathrm{R}$ under $\alpha-\mathrm{MHC}$ promoter (cardiomyocytes specific) (called Tg) (Jaffre et al., 2009). This cross generated various strains: $\mathrm{Tg} ; 5-\mathrm{HT}_{2 \mathrm{~B}} \mathrm{R}^{-/-}$(strain knockout for the $5-\mathrm{HT}_{2 \mathrm{~B}} \mathrm{R}$ in all cells except cardiomyocytes) and $\mathrm{Tg} ; 5-\mathrm{HT}_{2 \mathrm{~B}} \mathrm{R}^{+/+}$(strain expressing the 5- $\mathrm{HT}_{2 \mathrm{~B}} \mathrm{R}$ in all cells, including cardiomyocytes and fibroblasts). The cardiac hypertrophy induced by isoproterenol was completely suppressed in $\mathrm{Tg} ; 5-\mathrm{HT}_{2 \mathrm{~B}} \mathrm{R}^{-/}$showing that the $5-\mathrm{HT}_{2 \mathrm{~B}} \mathrm{R}$ localized in 
cardiomyocytes is not involved in the antihypertrophic effect of 5- $\mathrm{HT}_{2 \mathrm{~B}} \mathrm{R}$ blockade. Moreover, the plasma increase of IL- 6 , IL-1 $\beta$ and TGF- $\beta$ that was induced by isoproterenol in $\mathrm{Tg} ; 5-\mathrm{HT}_{2 \mathrm{~B}} \mathrm{R}^{+/+}$or $5-\mathrm{HT}_{2 \mathrm{~B}} \mathrm{R}^{+/+}$, was suppressed in $\mathrm{Tg} ; 5-\mathrm{HT}_{2 \mathrm{~B}} \mathrm{R}^{-/-}$, indicating the major contribution of extracellular cell matrix in the process of cardiac hypertrophy due to a chronic $\beta$-adrenergic stimulation. Similar results were obtained in primary cultures of left-ventricular fibroblasts coming from this later strain and identified the $5-\mathrm{HT}_{2 \mathrm{~B}} \mathrm{R}$ as a major contributor to cardiac hypertrophy triggered by both $\beta$-adrenergic and angiotensinergic stimulations (Figure 4). Finally, these findings were validated in humans, in which $5-\mathrm{HT}_{2 \mathrm{~B}} \mathrm{R}$ overexpression is correlated with plasma norepinephrine and cytokine levels.

Another insight of transgenic animals in cardiac remodeling is cardiac valve degeneration. Free plasma 5-HT is captured by cells expressing SERT. This capture is followed by the intracellular degradation of the transmitter mainly by MAO-A (Bianchi et al., 2005). Two transgenic mice revealed that a reduction of 5-HT catabolism could contribute to myocardial and valve fibrosis. In the first one, the genetic ablation of SERT lead to a cardiac fibrosis including the valves (Mekontso-Dessap et al., 2006). The study provided the first experimental evidence that an increase in extracellular 5-HT concentration could favor cardiac fibrosis. Similarly, MAO-A knockout mice submitted to cardiac hypertrophy by aortic constriction demonstrated an increase in plasma 5-HT, an exacerbation of cardiac hypertrophy and an increase in myocardial 5-HT content (Lairez et al., 2009). Taken together, these data emphasize the contribution of 5-HT in cardiac remodeling and gave new evidences about its role in valve degeneration. Serotonin plays a major role in the pathogenesis of the cardiac plaque formation and valvulopathy observed in carcinoid patients; heart diseased patients demonstrated strikingly higher mean serum 5-HT, plasma 5-HT, and urine 5-HIAA levels (Robiolio et al., 1995). This work open the way of future studies exploring the mechanisms of valve degeneration in the carcinoid heart, a situation where free plasma 5-HT is massively increased.

\section{Conclusions and future prospects}

Molecular genetics opened new areas of investigation in the field of 5-HT in the cardiovascular system. New targets and new clinical indications were proposed for drugs that would modulate 5-HT synthesis, transport and receptor-mediated effects. A lot of work has still to be done - we have yet to investigate all transgenics for every serotonergic molecule. Moreover, many of these proteins are polymorphic. It has been suggested that some 
polymorphisms may affect cardiovascular outcome (SERT) but humanized mice will probably help to better assess their contributions. Together with functional genomics, pharmacogenomics and classical pharmacological, molecular genetics is likely to help the development of new drug candidates to treat and/or prevent pulmonary hypertension, pulmonary fibrosis or cardiac hypertrophy. However, although work with transgenic rats and mice clearly has the potential to shed new light on the cardiovascular pharmacology of 5-HT, it should be borne in mind that neither mice nor rats are not small humans (Setola and Roth, 2003). 


\section{Legend to figures}

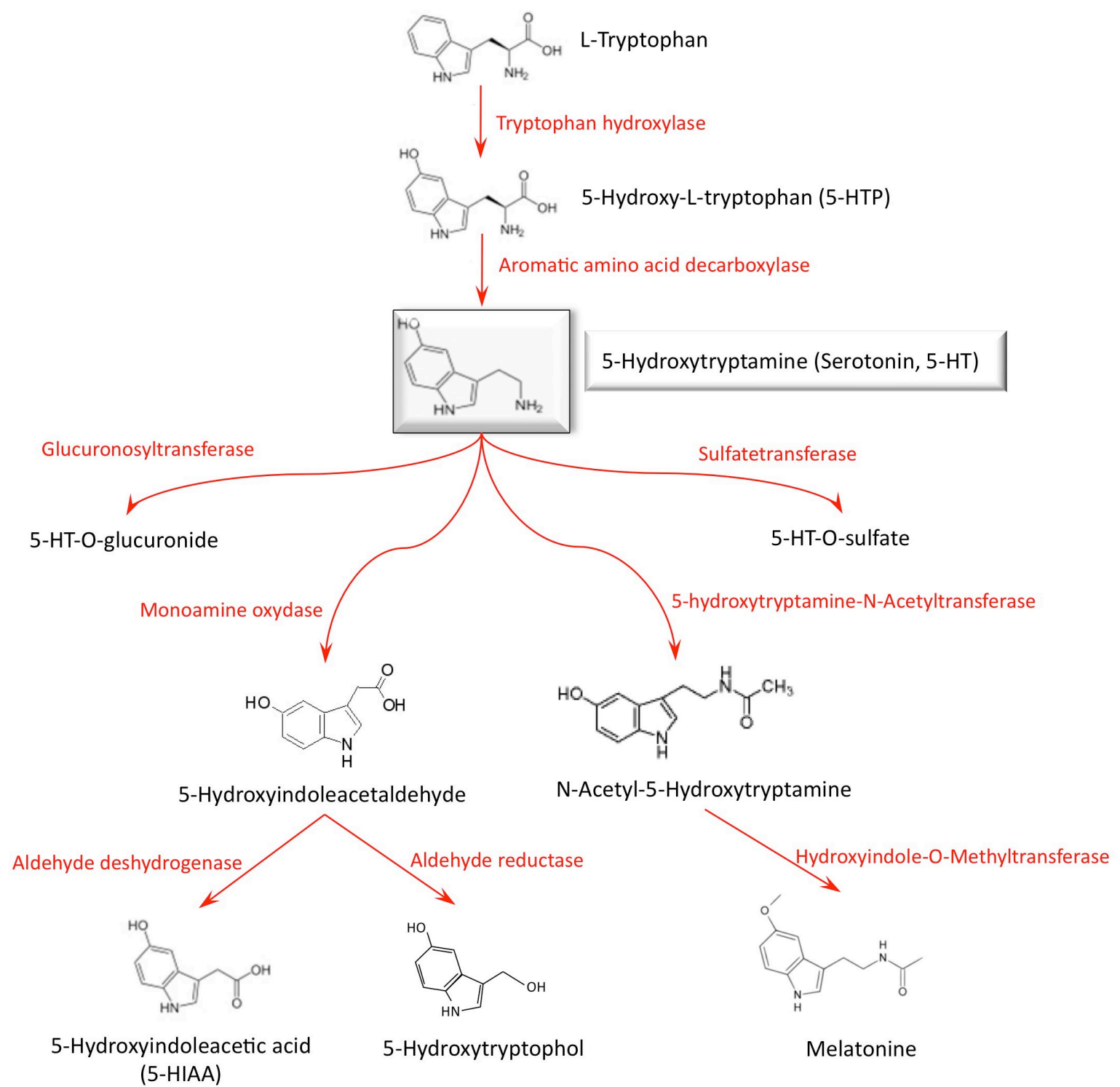

Figure 1 : Serotonin synthesis and catabolism. 


\section{Figure 2}

\section{5-HT TRANSPORT}

\section{SERT}

\section{ION CHANNELS}

$$
\begin{aligned}
& 5-\mathrm{HT}_{3 \mathrm{~A}} \\
& 5-\mathrm{HT}_{3 \mathrm{~B}} \\
& 5-\mathrm{HT}_{3 \mathrm{C}}
\end{aligned}
$$

\section{G PROTEIN-COUPLED RECEPTORS}
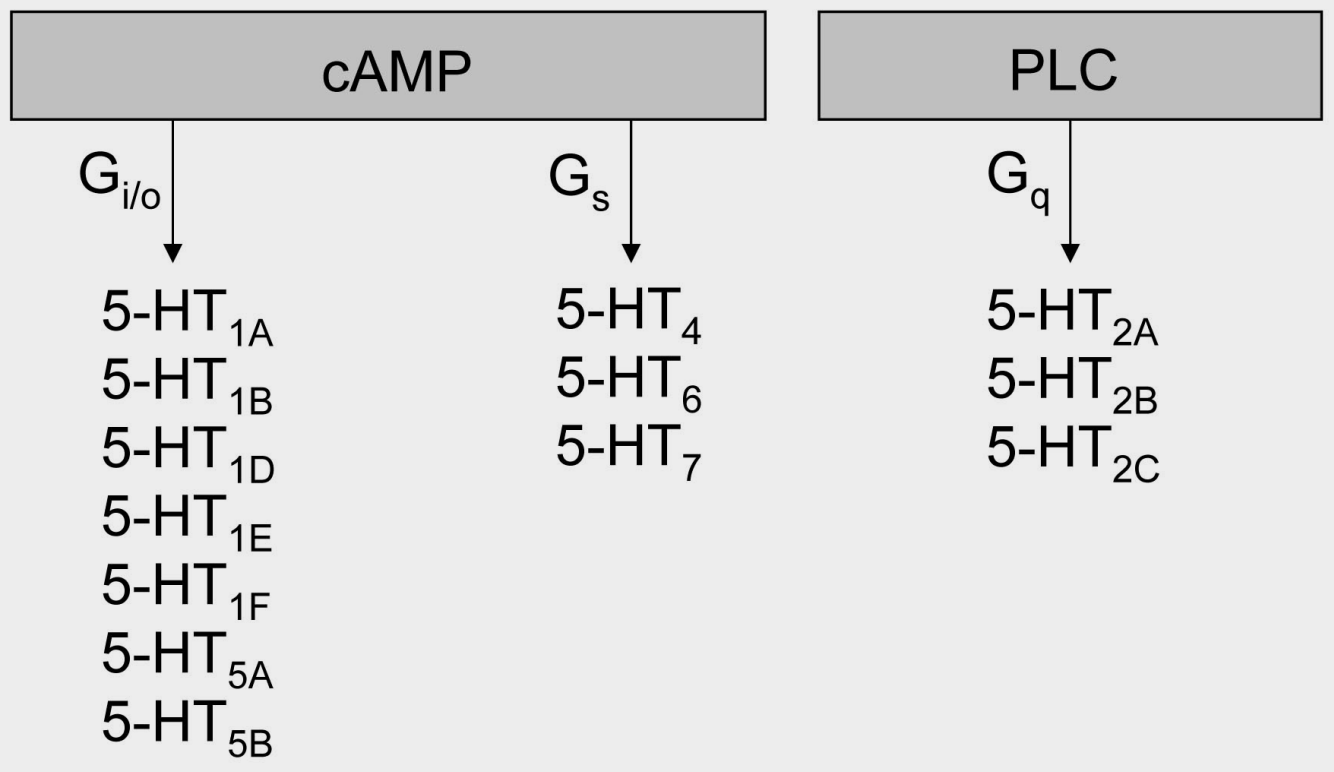

$5-\mathrm{HT}_{2 \mathrm{~A}}$

$5-\mathrm{HT}_{2 \mathrm{~B}}$

$5-\mathrm{HT}_{2 \mathrm{C}}$

Figure 2 : The 5-HT transporter and the 16 serotonergic receptors with their main signaling pathways. 


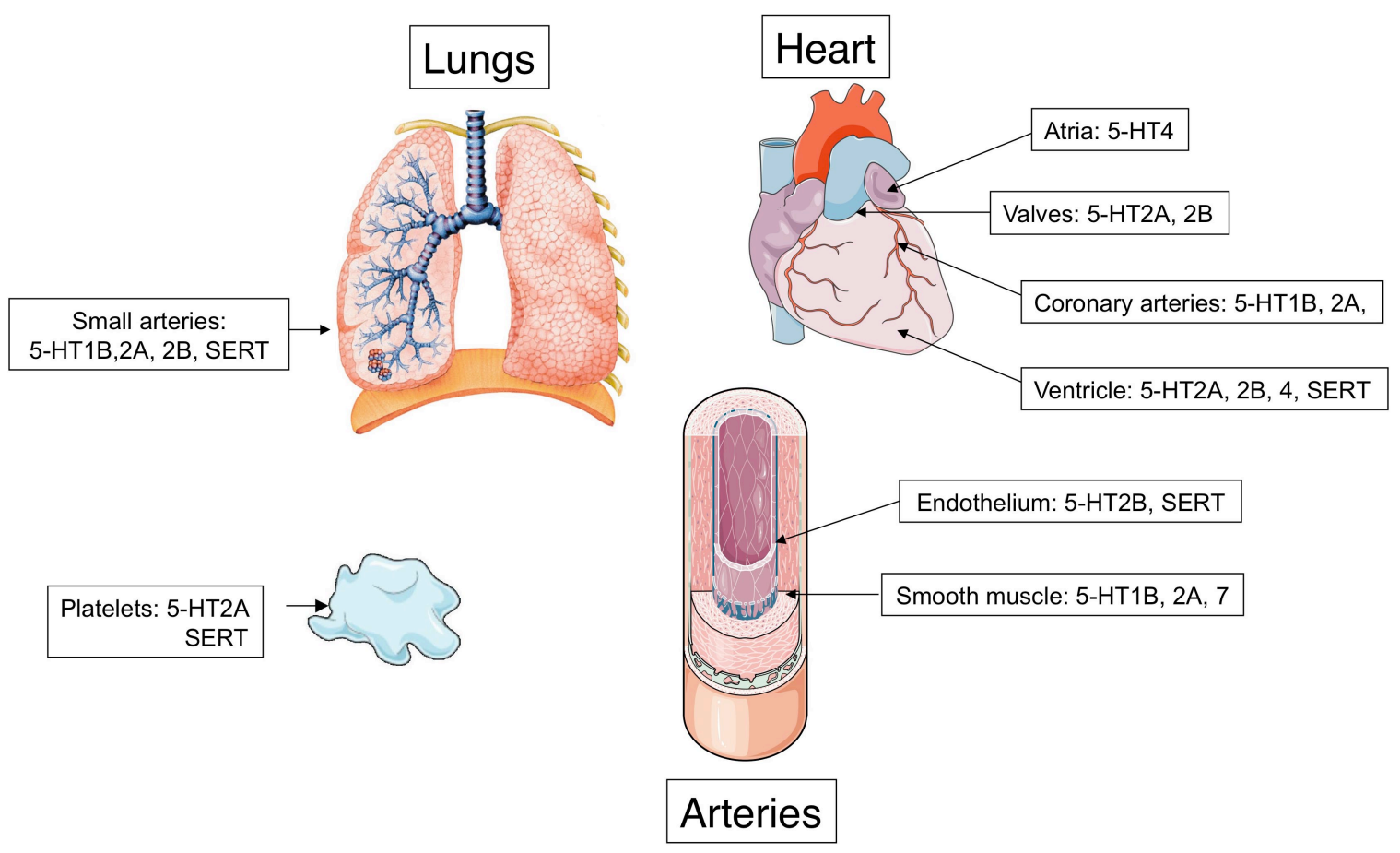

Figure 3: Distribution of 5-HT effectors in the cardiovascular system.

$5-\mathrm{HT}_{1 \mathrm{~B}}, 5-\mathrm{HT}_{2 \mathrm{~A}}$ and $5-\mathrm{HT}_{2 \mathrm{~B}}$ receptors are expressed by small pulmonary arteries. Serotonergic control of systemic vascular tone (including coronary arteries) mainly involves vascular $5-\mathrm{HT}_{2 \mathrm{~A}}$ and $5-\mathrm{HT}_{1 \mathrm{~B}}$ receptors. Vasodilatation in arteries follows activation of 5- $\mathrm{HT}_{7}$ receptors in smooth muscles and endothelial 5- $\mathrm{HT}_{2 \mathrm{~B}}$ receptors, which leads to NO release. Cardiac atrium express $5-\mathrm{HT}_{4}$ receptors (during development in rodent), and ventricles express $5-\mathrm{HT}_{1 \mathrm{~B}}, 5-\mathrm{HT}_{2 \mathrm{~A}}$ and $5-\mathrm{HT}_{4}$ receptors. $5-\mathrm{HT}_{2 \mathrm{~A}}$ and $5-\mathrm{HT}_{2 \mathrm{~B}}$ receptors are highly expressed in valves. Finally, matures platelets express $5-\mathrm{HT}_{2 \mathrm{~A}}$ receptors and SERT. 


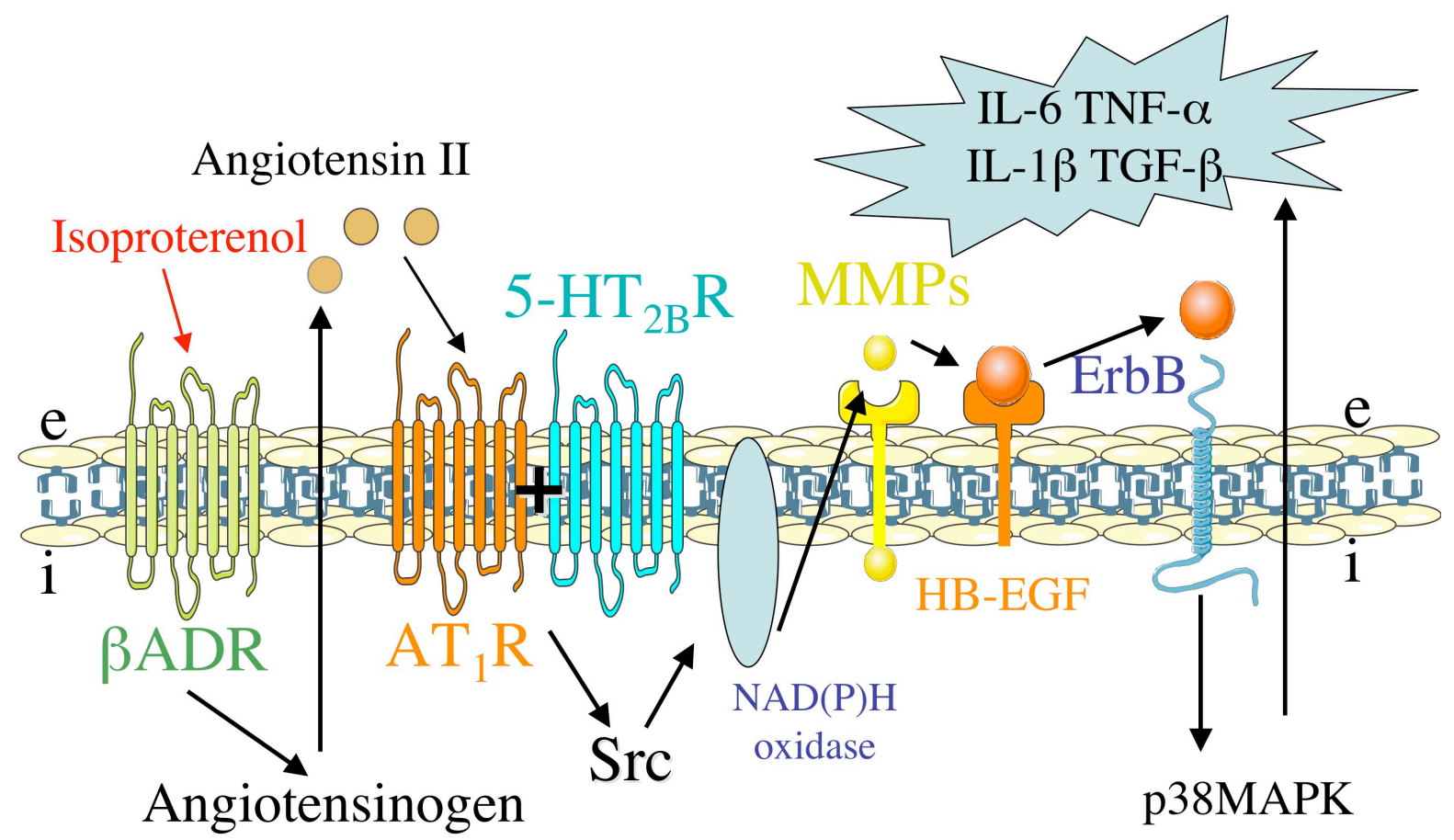

Figure 4: Molecular pathways involving serotonergic 5-HT $\mathbf{H B}_{2 \mathrm{~B}}$ receptors in cytokines secretion by cardiac fibroblasts.

Stimulation of $\beta$-adrenergic receptors in cardiac ventricular fibroblasts drives the formation of angiotensin II from angiotensinogen. Consecutive stimulation of $\mathrm{AT}_{1} / 5-\mathrm{HT}_{2 \mathrm{~B}}$ receptor complexes activates MMPs through Src and the NADP(H) oxidase, and then HB-EGF/ErbB signaling triggers cytokines release via p38 mitogen-activated protein kinase activation. This release can lead to paracrine effects in cardiomyocytes such as hypertrophy and may be involved in extracellular cell matrix remodeling by promoting inflammation and fibrosis. $\beta A D R$ : beta adrenergic receptor, $\mathrm{AT}_{1} \mathrm{R}$ : $\mathrm{AT}_{1}$ receptor for angiotensin, 5- $\mathrm{HT}_{2 \mathrm{~B}} \mathrm{R}: 5-\mathrm{HT}_{2 \mathrm{~B}}$ receptor, MMPs: matrix metalloproteinases, e: extracellular, i: intracellular. 


\section{Acknowledgements}

This work has been supported by funds from the Centre National de la Recherche Scientifique, the Institut National de la Santé et de la Recherche Médicale, the Université Pierre et Marie Curie, and by grants from the Fondation de France, the Fondation pour la Recherche Médicale, the Association pour la Recherche contre le Cancer, the French ministry of research (Agence Nationale pour la Recherche), and the European Commission (FP7health-2007-A-201714). LMa's team is an "Equipe Fondation pour la Recherche Médicale" and S. Doly is supported by a Lefoulon-Lalande fellowship..

\section{References}

Ahmed, B.A., Jeffus, B.C., Bukhari, S.I.A., Harney, J.T., Unal, R., Lupashin, V.V., van der Sluijs, P., and Kilic, F. (2008). Serotonin transamidates Rab4 and facilitates its binding to the C terminus of serotonin transporter. J Biol Chem 283, 9388-9398.

Angeles, D.M., Williams, J., Purdy, R.E., Zhang, L., and Pearce, W.J. (2001). Effects of maturation and acute hypoxia on receptor-IP(3) coupling in ovine common carotid arteries. Am J Physiol Regul Integr Comp Physiol 280, R410-417.

Angeles, D.M., Williams, J., Zhang, L., and Pearce, W.J. (2000). Acute hypoxia modulates 5HT receptor density and agonist affinity in fetal and adult ovine carotid arteries. Am $\mathbf{J}$ Physiol Heart Circ Physiol 279, H502-510.

Banes, A.K., and Watts, S.W. (2003). Arterial Expression of 5- $\mathrm{HT}_{2 \mathrm{~B}}$ and 5-HT $1 \mathrm{~B}$ Receptors During Development of DOCA-salt Hypertension. BMC Pharmacol 3, 12.

Bhat, G.B., and Block, E.R. (1990). Hypoxia directly increases serotonin transport by porcine pulmonary artery endothelial cell plasma membrane vesicles. Am J Respir Cell Mol Biol 3, 363-367.

Bianchi, P., Kunduzova, O., Masini, E., Cambon, C., Bani, D., Raimondi, L., Seguelas, M.H., Nistri, S., Colucci, W., Leducq, N., et al. (2005). Oxidative stress by monoamine oxidase mediates receptor-independent cardiomyocyte apoptosis by serotonin and postischemic myocardial injury. Circulation 112, 3297-3305.

Brune, S., Schmidt, T., Tebbe, U., and Kreuzer, H. (1990). Influence of long-term treatment with ketanserin on blood pressure, pulmonary artery pressure, and cardiac output in patients with heart failure. Cardiovasc Drugs Ther of Cardiovascular Pharmacotherapy 4 Suppl 1, 85-87.

Berul CI, Christe ME, Aronovitz MJ, et al. (1998) Familial hypertrophic cardiomyopathy mice display gender differences in electrophysiological abnormalities. J Interv Card Electrophysiol. 2, 7-14.

Callebert, J., Esteve, J.M., Hervé, P., Peoc'h, K., Tournois, C., Drouet, L., Launay, J.M., and Maroteaux, L. (2006). Evidence for a control of plasma serotonin levels by 5Hydroxytryptamine $_{2 \mathrm{~B}}$ receptors in mice. J Pharmacol Exp Ther 317, 724-731.

Carneiro, A.M., Cook, E.H., Murphy, D.L., and Blakely, R.D. (2008). Interactions between integrin alphaIIbbeta3 and the serotonin transporter regulate serotonin transport and platelet aggregation in mice and humans. J Clin Invest 118, 1544-1552.

Choi, D.S., Ward, S.J., Messaddeq, N., Launay, J.M., and Maroteaux, L. (1997). 5-HT 2 B receptor-mediated serotonin morphogenetic functions in mouse cranial neural crest and myocardiac cells. Development 124, 1745-1755. 
Cook, E.H., Jr., Fletcher, K.E., Wainwright, M., Marks, N., Yan, S.Y., and Leventhal, B.L. (1994). Primary structure of the human platelet serotonin 5- $\mathrm{HT}_{2 \mathrm{~A}}$ receptor: identify with frontal cortex serotonin 5- $\mathrm{HT}_{2 \mathrm{~A}}$ receptor. J Neurochem 63, 465-469.

Cote, F., Fligny, C., Bayard, E., Launay, J.M., Gershon, M.D., Mallet, J., and Vodjdani, G. (2007). Maternal serotonin is crucial for murine embryonic development. Proc Natl Acad Sci U S A 104, 329-334.

Côté, F., Thevenot, E., Fligny, C., Fromes, Y., Darmon, M., Ripoche, M.A., Bayard, E., Hanoun, N., Saurini, F., Lechat, P., et al. (2003). Disruption of the nonneuronal tph1 gene demonstrates the importance of peripheral serotonin in cardiac function. Proc Natl Acad Sci U S A 100, 13525-13530.

Dai, Y., Dudek, N.L., Patel, T.B., and Muma, N.A. (2008). Transglutaminase-catalyzed Transamidation: A Novel Mechanism for Rac1 Activation by 5- $\mathrm{HT}_{2 \mathrm{~A}}$ Receptor Stimulation. J Pharmacol Exp Ther.

Dale, G.L., Friese, P., Batar, P., Hamilton, S.F., Reed, G.L., Jackson, K.W., Clemetson, K.J., and Alberio, L. (2002). Stimulated platelets use serotonin to enhance their retention of procoagulant proteins on the cell surface. Nature 415, 175-179.

Davidson, C., and Stamford, J.A. (1996). Serotonin efflux in the rat ventral lateral geniculate nucleus assessed by fast cyclic voltammetry is modulated by $5-\mathrm{HT}_{1 \mathrm{~B}}$ and $5-\mathrm{HT} 1 \mathrm{D}$ autoreceptors. Neuropharmacology 35, 1627-1634.

Eddahibi, S., Fabre, V., Boni, C., Martres, M.P., Raffestin, B., Hamon, M., and Adnot, S. (1999). Induction of serotonin transporter by hypoxia in pulmonary vascular smooth muscle cells. Relationship with the mitogenic action of serotonin. Circ Res 84, 329-336.

Eddahibi, S., Hanoun, N., Lanfumey, L., Lesch, K.P., Raffestin, B., Hamon, M., and Adnot, S. (2000). Attenuated hypoxic pulmonary hypertension in mice lacking the 5hydroxytryptamine transporter gene. J Clin Invest 105, 1555-1562.

Esteve, J.M., Launay, J.M., Kellermann, O., and Maroteaux, L. (2007). Functions of serotonin in hypoxic pulmonary vascular remodeling. Cell Biochem Biophys 47, 33-44.

Fanburg, B.L., and Lee, S.L. (2000). A role for the serotonin transporter in hypoxia-induced pulmonary hypertension. J Clin Invest 105, 1521-1523.

Farber, H.W., and Loscalzo, J. (2004). Pulmonary arterial hypertension. N Engl J Med 351, $1655-1665$.

Fligny, C., Fromes, Y., Bonnin, P., Darmon, M., Bayard, E., Launay, J.M., Cote, F., Mallet, J., and Vodjdani, G. (2008). Maternal serotonin influences cardiac function in adult offspring. FASEB J 22, 2340-2349.

Fu, X.W., Nurse, C.A., Wong, V., and Cutz, E. (2002). Hypoxia-induced secretion of serotonin from intact pulmonary neuroepithelial bodies in neonatal rabbit. J Physiol 539, 503-510.

Guilluy, C., Eddahibi, S., Agard, C., Guignabert, C., Izikki, M., Tu, L., Savale, L., Humbert, M., Fadel, E., Adnot, S., et al. (2009). RhoA and Rho kinase activation in human pulmonary hypertension: role of 5-HT signaling. American Journal of Respiratory and Critical Care Medicine 179, 1151-1158.

Guilluy, C., Rolli-Derkinderen, M., Tharaux, P.L., Melino, G., Pacaud, P., and Loirand, G. (2007). Transglutaminase-dependent RhoA activation and depletion by serotonin in vascular smooth muscle cells. J Biol Chem 282, 2918-2928.

Herve, P., Drouet, L., Dosquet, C., Launay, J.M., Rain, B., Simonneau, G., Caen, J., and Duroux, P. (1990). Primary pulmonary hypertension in a patient with a familial platelet storage pool disease: role of serotonin. Am J Med 89, 117-120.

Herve, P., Launay, J.M., Scrobohaci, M.L., Brenot, F., Simonneau, G., Petitpretz, P., Poubeau, P., Cerrina, J., Duroux, P., and Drouet, L. (1995). Increased plasma serotonin in primary pulmonary hypertension. Am J Med 99, 249-254. 
Homberg, J., Mudde, J., Braam, B., Ellenbroek, B., Cuppen, E., and Joles, J.A. (2006). Blood pressure in mutant rats lacking the 5-hydroxytryptamine transporter. Hypertension 48, e115-116; author reply e117.

Homberg, J.R., Pattij, T., Janssen, M.C., Ronken, E., De Boer, S.F., Schoffelmeer, A.N., and Cuppen, E. (2007). Serotonin transporter deficiency in rats improves inhibitory control but not behavioural flexibility. Eur J Neurosci 26, 2066-2073.

Jaffre, F., Bonnin, P., Callebert, J., Debbabi, H., Setola, V., Doly, S., Monassier, L., Mettauer, B., Blaxall, B.C., Launay, J.M., et al. (2009). Serotonin and angiotensin receptors in cardiac fibroblasts coregulate adrenergic-dependent cardiac hypertrophy. Circ Res 104, 113-123.

Jaffre, F., Callebert, J., Sarre, A., Etienne, N., Nebigil, C.G., Launay, J.M., Maroteaux, L., and Monassier, L. (2004). Involvement of the serotonin 5- $\mathrm{HT}_{2 \mathrm{~B}}$ receptor in cardiac hypertrophy linked to sympathetic stimulation: control of interleukin-6, interleukin-1B eta, and tumor necrosis factor-alpha cytokine production by ventricular fibroblasts. Circulation 110, 969-974.

Jeffery, T.K., and Wanstall, J.C. (2001). Pulmonary vascular remodeling: a target for therapeutic intervention in pulmonary hypertension. Pharmacol Ther 92, 1-20.

Jonnakuty, C, and Gragnoli, C (2008). What do we know about serotonin? J Cell Physiol. 217(2):301-6. Review.

Kamel, R., Garcia, S., Lezoualc'h, F., Fischmeister, R., Muller, S., Hoebek, J., and Eftekhari, P. (2007). Immunomodulation by maternal autoantibodies of the fetal serotoninergic 5HT4 receptor and its consequences in early BALB/c mouse embryonic development. BMC Dev Biol 7, 34.

Keegan, A., Morecroft, I., Smillie, D., Hicks, M.N., and MacLean, M.R. (2001). Contribution of the 5-HT(18) receptor to hypoxia-induced pulmonary hypertension: converging evidence using 5-HT( $\left.{ }_{1 \mathrm{~B}}\right)$-receptor knockout mice and the 5-HT( $\left.{ }_{1 \mathrm{~B}} / 1 \mathrm{D}\right)$-receptor antagonist GR127935. Circ Res 89, 1231-1239.

Keith, I.M., Will, J.A., Huxtable, R.J., and Weir, K. (1987). Anti-platelet agents reduce morphological changes of chronic hypoxic pulmonary hypertension. Histol Histopathol 2, 203-206.

Kentera, D., Susic, D., Veljkovic, V., Tucakovic, G., and Koko, V. (1988). Pulmonary artery pressure in rats with hereditary platelet function defect. Respiration 54, 110-114.

Kereveur, A., Callebert, J., Humbert, M., Herve, P., Simonneau, G., Launay, J.M., and Drouet, L. (2000). High plasma serotonin levels in primary pulmonary hypertension. Effect of long-term epoprostenol (prostacyclin) therapy. Arterioscler Thromb Vasc Biol 20, 2233-2239.

Kirby, G.C., and McQueen, D.S. (1984). Effects of the antagonists MDL 72222 and ketanserin on responses of cat carotid body chemoreceptors to 5-hydroxytryptamine. Br J Pharmacol 83, 259-269.

Lairez, O., Calise, D., Bianchi, P., Ordener, C., Spreux-Varoquaux, O., Guilbeau-Frugier, C., Escourrou, G., Seif, I., Roncalli, J., Pizzinat, N., et al. (2009). Genetic deletion of MAOA promotes serotonin-dependent ventricular hypertrophy by pressure overload. J Mol Cell Cardiol 46, 587-595.

Lauder, J.M., Wilkie, M.B., Wu, C., and Singh, S. (2000). Expression of 5-HT(2A), 5-HT(2B) and 5-HT(2C) receptors in the mouse embryo. Int J Dev Neurosci 18, 653-662.

Launay, J.M., Herve, P., Peoc'h, K., Tournois, C., Callebert, J., Nebigil, C.G., Etienne, N., Drouet, L., Humbert, M., Simonneau, G., et al. (2002). Function of the serotonin 5hydroxytryptamine $_{2 \mathrm{~B}}$ receptor in pulmonary hypertension. Nat Med 8, 1129-1135. 
Launay, J.M., Loric, S., Mutel, V., and Kellermann, O. (1998). The 5-HT2B receptor controls the overall 5-HT transport system in the 1C11 serotonergic cell line. Ann N Y Acad Sci $861,247$.

Lee, S.L., Wang, W.W., Moore, B.J., and Fanburg, B.L. (1991). Dual effect of serotonin on growth of bovine pulmonary artery smooth muscle cells in culture. Circ Res 68, 13621368.

Li, N., Wallen, N.H., Ladjevardi, M., and Hjemdahl, P. (1997). Effects of serotonin on platelet activation in whole blood. Blood Coagul Fibrinolysis 8, 517-523.

Linder, A.E., Ni, W., Szasz, T., Burnett, R., Diaz, J., Geddes, T.J., Kuhn, D.M., and Watts, S.W. (2008). A serotonergic system in veins: serotonin transporter-independent uptake. J Pharmacol Exp Ther 325, 714-722.

MacLean, M.R., Deuchar, G.A., Hicks, M.N., Morecroft, I., Shen, S., Sheward, J., Colston, J., Loughlin, L., Nilsen, M., Dempsie, Y., et al. (2004). Overexpression of the 5hydroxytryptamine transporter gene: effect on pulmonary hemodynamics and hypoxiainduced pulmonary hypertension. Circulation 109, 2150-2155.

Marcos, E., Adnot, S., Pham, M.H., Nosjean, A., Raffestin, B., Hamon, M., and Eddahibi, S. (2003). Serotonin transporter inhibitors protect against hypoxic pulmonary hypertension. Am J Respir Crit Care Med 168, 487-493.

Matondo, R.B., Punt, C., Homberg, J., Toussaint, M.J., Kisjes, R., Korporaal, S.J., Akkerman, J.W., Cuppen, E., and de Bruin, A. (2009). Deletion of the serotonin transporter in rats disturbs serotonin homeostasis without impairing liver regeneration. Am J Physiol Gastrointest Liver Physiol 296, G963-968.

McDonald, T.P., Cottrell, M., and Clift, R. (1978). Effects of short-term hypoxia on platelet counts of mice. Blood 51, 165-175.

McDonald, T.P., Cottrell, M.B., Steward, S.A., Clift, R.E., Swearingen, C.J., and Jackson, C.W. (1992). Comparison of platelet production in two strains of mice with different modal megakaryocyte DNA ploidies after exposure to hypoxia. Exp Hematol 20, 51-56.

Mekontso-Dessap, A., Brouri, F., Pascal, O., Lechat, P., Hanoun, N., Lanfumey, L., Seif, I., Benhaiem-Sigaux, N., Kirsch, M., Hamon, M., et al. (2006). Deficiency of the 5hydroxytryptamine transporter gene leads to cardiac fibrosis and valvulopathy in mice. Circulation 113, 81-89.

Monassier, L., Laplante, M.A., Jaffre, F., Bousquet, P., Maroteaux, L., and de Champlain, J. (2008). Serotonin 5-HT(2B) receptor blockade prevents reactive oxygen species-induced cardiac hypertrophy in mice. Hypertension 52, 301-307.

Morecroft, I., Dempsie, Y., Bader, M., Walther, D.J., Kotnik, K., Loughlin, L., Nilsen, M., and MacLean, M.R. (2007). Effect of tryptophan hydroxylase 1 deficiency on the development of hypoxia-induced pulmonary hypertension. Hypertension 49, 232-236.

Morecroft, I., Loughlin, L., Nilsen, M., Colston, J., Dempsie, Y., Sheward, J., Harmar, A., and MacLean, M.R. (2005). Functional interactions between 5-hydroxytryptamine receptors and the serotonin transporter in pulmonary arteries. J Pharmacol Exp Ther 313, 539-548.

Nebigil, C.G., Hickel, P., Messaddeq, N., Vonesch, J.L., Douchet, M.P., Monassier, L., Gyorgy, K., Matz, R., Andriantsitohaina, R., Manivet, P., et al. (2001). Ablation of serotonin $5-\mathrm{HT}(2 \mathrm{~B})$ receptors in mice leads to abnormal cardiac structure and function. Circulation 103, 2973-2979.

Nebigil, C.G., Jaffre, F., Messaddeq, N., Hickel, P., Monassier, L., Launay, J.M., and Maroteaux, L. (2003). Overexpression of the serotonin 5- $\mathrm{HT}_{2 \mathrm{~B}}$ receptor in heart leads to abnormal mitochondrial function and cardiac hypertrophy. Circulation 107, 3223-3229. 
Ni, W., Geddes, T.J., Priestley, J.R., Szasz, T., Kuhn, D.M., and Watts, S.W. (2008). The existence of a local 5-hydroxytryptaminergic system in peripheral arteries. $\mathrm{Br} \mathrm{J}$ Pharmacol 154, 663-674.

Ni, W., Wilhelm, C.S., Bader, M., Murphy, D.L., Lookingland, K., and Watts, S.W. (2005). $(+)$-Norfenfluramine-induced arterial contraction is not dependent on endogenous 5hydroxytryptamine or 5-hydroxytryptamine transporter. J Pharmacol Exp Ther 314, 953960.

Paulmann, N., Grohmann, M., Voigt, J.-P., Bert, B., Vowinckel, J., Bader, M., Skelin, M., Jevsek, M., Fink, H., Rupnik, M., et al. (2009). Intracellular serotonin modulates insulin secretion from pancreatic beta-cells by protein serotonylation. PLoS Biol 7, e1000229.

Pavone, L.M., Mithbaokar, P., Mastellone, V., Avallone, L., Gaspar, P., Maharajan, V., and Baldini, A. (2007). Fate map of serotonin transporter-expressing cells in developing mouse heart. Genesis 45, 689-695.

Pavone, L.M., Spina, A., Lo Muto, R., Santoro, D., Mastellone, V., and Avallone, L. (2008). Heart valve cardiomyocytes of mouse embryos express the serotonin transporter SERT. Biochem Biophys Res Commun 377, 419-422.

Pitt, B.R., Weng, W., Steve, A.R., Blakely, R.D., Reynolds, I., and Davies, P. (1994). Serotonin increases DNA synthesis in rat proximal and distal pulmonary vascular smooth muscle cells in culture. Am J Physiol 266, L178-186.

Qvigstad E, Brattelid T, Sjaastad I, Andressen KW, Krobert KA, Birkeland JA, Sejersted OM, Kaumann AJ, Skomedal T, Osnes JB, et al. (2005) Appearance of a ventricular 5-HT4 receptor-mediated inotropic response to serotonin in heart failure. Cardiovasc Res. 65(4), 869-78.

Rabinovitch, M. (2001). Linking a serotonin transporter polymorphism to vascular smooth muscle proliferation in patients with primary pulmonary hypertension. J Clin Invest 108, 1109-1111.

Rapport, M.M., Green, A.A., and Page, I.H. (1948a). Crystalline Serotonin. Science 108, 329330.

Rapport, M.M., Green, A.A., and Page, I.H. (1948b). Serum vasoconstrictor, serotonin; isolation and characterization. J Biol Chem 176, 1243-1251.

Reeves, J.T., Groves, B.M., and Turkevich, D. (1986). The case for treatment of selected patients with primary pulmonary hypertension. Am Rev Respir Dis 134, 342-346.

Robiolio, P.A., Rigolin, V.H., Wilson, J.S., Harrison, J.K., Sanders, L.L., Bashore, T.M., and Feldman, J.M. (1995). Carcinoid heart disease. Correlation of high serotonin levels with valvular abnormalities detected by cardiac catheterization and echocardiography. Circulation 92, 790-795.

Rostagno, C., Prisco, D., Boddi, M., and Poggesi, L. (1991). Evidence for local platelet activation in pulmonary vessels in patients with pulmonary hypertension secondary to chronic obstructive pulmonary disease. Eur Respir J 4, 147-151.

Roux, C., Madani, M., Launay, J.-M., Rey, F., Citadelle, D., Mulliez, N., and Kolf, M. (1995). Serotonin deficiency in phenylketonuria embryopathy. Toxicol in Vitro 9, 653662.

Sanchez, C., and Hyttel, J. (1999). Comparison of the effects of antidepressants and their metabolites on reuptake of biogenic amines and on receptor binding. Cell Mol Neurobiol 19, 467-489.

Sato, K., Webb, S., Tucker, A., Rabinovitch, M., O'Brien, R.F., McMurtry, I.F., and Stelzner, T.J. (1992). Factors influencing the idiopathic development of pulmonary hypertension in the fawn hooded rat. Am Rev Respir Dis 145, 793-797. 
Setola, V., and Roth, B.L. (2003). Why mice are neither miniature humans nor small rats: a cautionary tale involving 5-hydroxytryptamine-6 serotonin receptor species variants. Mol Pharmacol 64, 1277-1278.

Steele, P., Ellis, J.H., Jr., Weily, H.S., and Genton, E. (1977). Platelet survival time in patients with hypoxemia and pulmonary hypertension. Circulation 55, 660-661.

Tolmachova, T., Abrink, M., Futter, C.E., Authi, K.S., and Seabra, M.C. (2007). Rab27b regulates number and secretion of platelet dense granules. Proc Natl Acad Sci U S A 104, $5872-5877$.

Tournois, C., Mutel, V., Manivet, P., Launay, J.M., and Kellermann, O. (1998). Cross-talk between 5-hydroxytryptamine receptors in a serotonergic cell line. Involvement of arachidonic acid metabolism. J Biol Chem 273, 17498-17503.

Tu, D.N., Zou, A.R., Liao, Y.H., Du, Y.M., Wang, X.P., and Li, L. (2008). Blockade of the human ether-a-go-go-related gene potassium channel by ketanserin. Sheng Li Xue Bao $60,525-534$.

Vane, J.R. (1957). A sensitive method for the assay of 5-hydroxytryptamine. Br J Pharmacol Chemother 12, 344-349.

Vially, M., and Erspamer, V. (1933). Cellule entreocromaffine e cellule basigranulose acidofile nei vertebrati. Zeitschr f Zellforsch 19, 743-773.

Vyssoulis, G.P., Karpanou, E.A., Pitsavos, C.E., Paleologos, A.A., Kourtis, T.K., and Toutouzas, P.K. (1990). Left ventricular hypertrophy regression and function changes with ketanserin in elderly hypertensives. Cardiovasc Drugs Ther 4, 81-84.

Walther, D.J., Peter, J.U., Winter, S., Holtje, M., Paulmann, N., Grohmann, M., Vowinckel, J., Alamo-Bethencourt, V., Wilhelm, C.S., Ahnert-Hilger, G., et al. (2003). Serotonylation of small GTPases is a signal transduction pathway that triggers platelet alpha-granule release. Cell 115, 851-862.

Wanstall JC, Fiore SA, Gambino A, Chess-Williams R (2003). Potentiation of 5hydroxytryptamine (5-HT) responses by a 5-HT uptake inhibitor in pulmonary and systemic vessels: effects of exposing rats to hypoxia. Naunyn Schmiedebergs Arch Pharmacol. 368(6), 520-7.

Watts, S.W. (2009). The love of a lifetime: 5-HT in the cardiovascular system. Am J Physiol Regul Integr Comp Physiol 296, R252-256.

Watts, S.W., Priestley, J.R.C., and Thompson, J.M. (2009). Serotonylation of vascular proteins important to contraction. PLoS ONE 4, e5682.

Weiss, O. (1896). Über die Wirkungen von Blutserum-Injectionen ins Blut. Archiv für die Gesamte Physiologie des Menschen und der Thiere. LXV, 215-230.

Woulfe, D.S., Lilliendahl, J.K., August, S., Rauova, L., Kowalska, M.A., Abrink, M., Pejler, G., White, J.G., and Schick, B.P. (2008). Serglycin proteoglycan deletion induces defects in platelet aggregation and thrombus formation in mice. Blood 111, 3458-3467. 